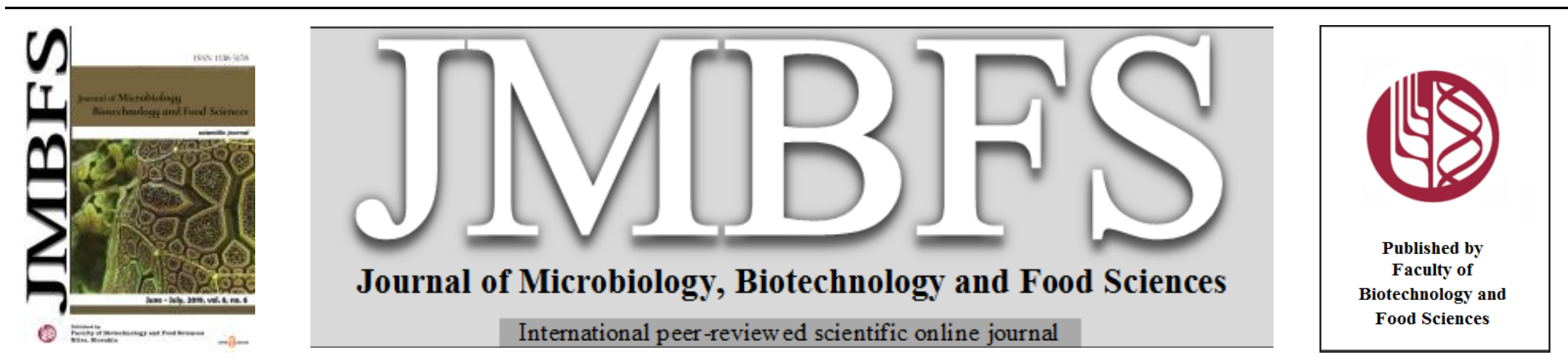

\title{
MICROBIAL DIVERSITY AND PHYSICO-CHEMICAL ATTRIBUTES OF TWO HOT WATER SPRINGS IN THE GARHWAL HIMALAYA, INDIA
}

\author{
Rahul Kumar* and Ramesh C. Sharma
}

Address(es): Rahul Kumar,

Laboratory of Environmental Microbiology and Biotechnology, Department of Environmental Sciences, H.N.B. Garhwal University (A Central University), Srinagar Garhwal- 246174, Uttarakhand, India.

*Corresponding author: rahul.khadwalia@gmail.com

doi: 10.15414/jmbfs.2019.8.6.1249-1253

\section{ARTICLE INFO}

Received 8. 3. 2018

Revised 28. 1. 2019

Accepted 29. 1. 2019

Published 1. 6. 2019

Regular article

open $\odot$ access

\begin{abstract}
The water samples were collected from two different hot water springs (Ringigad and Saldhar) of the Garhwal Himalaya for a period of two years. During the study period, the water sample was collected two times (June and August) each year for the analysis of physicochemical attributes and isolated microorganisms including bacteria, archaea and fungi. A total of fifteen physico-chemical parameters were studied during the study period that includes the water temperature, dissolved oxygen, $\mathrm{pH}$, conductivity, free carbondioxide, salinity, total dissolved solids, chlorides, total alkalinity, nitrates, sulphates, phosphates, total hardness, calcium and magnesium. Seven bacterial strains along with four archaeal and three fungal strains were isolated and identified in Ringigad thermal spring with $\alpha$ diversity of 14. However, the $\alpha$-diversity in Saldhar thermal spring was recorded to be 12 with six bacterial, three archaeal and three fungal strains. The temperature of water ranged between $82^{\circ} \mathrm{C}$ and $89^{\circ} \mathrm{C}$ for Ringigad and between $87^{\circ} \mathrm{C}$ and $92^{\circ} \mathrm{C}$ for Saldhar.
\end{abstract}

Keywords: Microbial diversity; Physico-chemical properties; Ringigad; Saldhar; Garhwal Himalaya, India

\section{INTRODUCTION}

Microorganisms populate in almost every possible region on the earth from those providing favorable circumstances for their survival and reproduction to those offering the severe or extreme conditions for their growth. The microorganisms that can survive in such extreme conditions are widely known as extremophiles. Among the extremophiles, thermophiles have received a huge attention in recent years because of their capability to survive at a very high temperature; even, they are active at an elevated temperature (Beg $\boldsymbol{e t}$ al., 2000; Bharadwaj $\boldsymbol{e t}$ al., 2010 Akmar et al., 2011; Huang et al., 2011).

Thermophilic microbes are found in various biotopes such as thermal springs, geothermal sediments and marine solfataras (Rothschild and Manicineli, 2001; Pathak and Rathod, 2014). Thermal springs are having very high water temperature or in other words we can say that the temperature is much more than the surroundings (Sen et al., 2010).

Thermal springs are the proofs of geological activity that indicate very high temperature and widely available in the Himalayan region (Kumar et al., 2004). Thermal springs are the affluent source of thermophilic microorganisms which can be tapped for various applications in different fields. Thermophilic microbes are containing enzymes that are stable at a very high temperature, which make them useful for the pharmaceutical, biotechnological, food processing and chemical industries (Tekere $\boldsymbol{e t}$ al., 2015). Physico-chemical properties are also playing an important role in the density and diversity of microbes in the thermal springs.

Though a lot of work has been done on various aspects of thermal springs that includes the works of Kumar et al., (2004) on soil microbial diversity from two different thermal springs of Uttarakhand, Sharma et al., (2008) on characterization and identification of various strains of Geobacillus spp. enumerated from Saldhar thermal spring; Akmar et al., (2011) on isolation of new thermophilic bacteria from hot spring; Bhusare and Wakte, (2011) on ho water spring of Unkeshwar; Ghati et al., (2013) on Esterolytic thermophilic bacteria from an Indian hot spring; Pathak and Rathod, (2014) on culturable diversity of bacteria in the thermal spring of Unkeshwar, India; Rawat, (2015) on bacterial diversity of a sulphur spring in Uttarakhand and Tekere $\boldsymbol{e t}$ al., (2015) on bacterial diversity in some African thermal springs. But no work has been done so far on the microbial diversity and physico-chemical attributes in the water of Ringigad and Saldhar thermal springs. Therefore, a maiden attempt has been made to provide basic data on microbial diversity and physico-chemical characteristics of Ringigad and Saldhar hot water spring for further studies.

\section{MATERIALS AND METHODS}

Study area

Ringigad is a thermal spring located at $17 \mathrm{Km}$ from Joshimath towards Suraithota (Figure 1) between latitude $30^{\circ} 33^{\prime} 14{ }^{\prime \prime} \mathrm{N}$ and longitude $79^{\circ} 40^{\prime} 0.06$ ' $\mathrm{E}$ at an altitude of $1,850 \mathrm{~m}$ above mean sea level in the Chamoli district of Uttarakhand. The approximate area covered by this hot water spring is $45 \mathrm{~m}^{2}$. The maximum in-situ temperature of Ringigad hot water spring is $89^{\circ} \mathrm{C}$.

However, Saldhar is also a thermal spring located at $19 \mathrm{Km}$ from Joshimath towards Suraithota (Figure 2) just near to the road on the right side. It is situated between latitude $39^{\circ} 29^{\prime} 25^{\prime \prime} \mathrm{N}$ and $79^{0} 39^{\prime} 29^{\prime \prime} \mathrm{E}$ at an altitude of 1,900 $\mathrm{m}$ above mean sea level in the Chamoli district of Uttarakhand. The approximate area that is covered by this hot water spring was $70 \mathrm{~m}^{2}$. The maximum in-situ temperature of Saldhar is $92^{\circ} \mathrm{C}$.

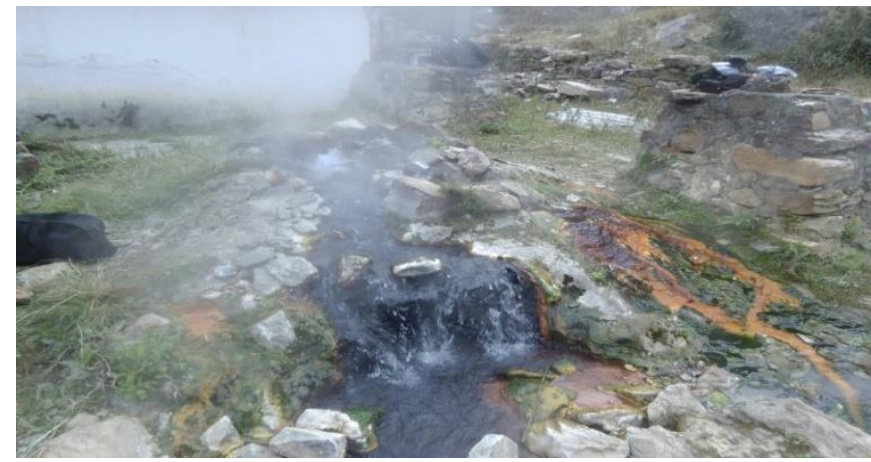

Figure 1 Study area (Ringigad, a thermal spring near Joshimath) 


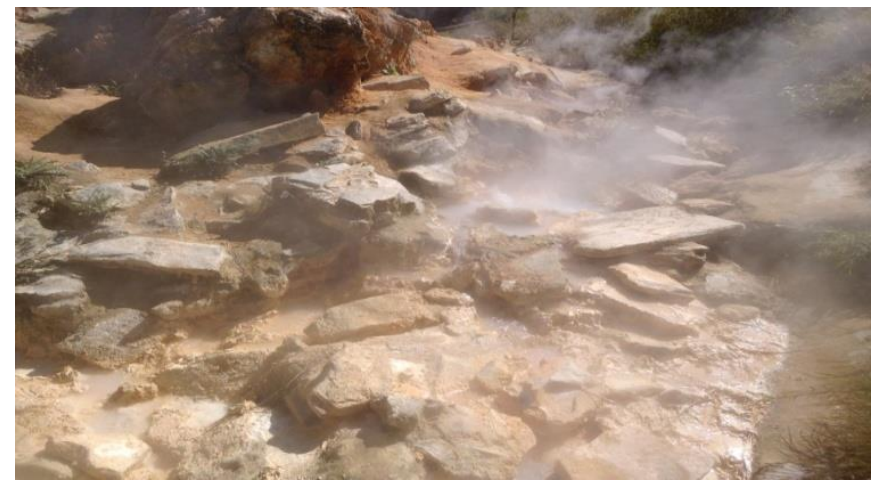

Figure 2 Study area (Saldhar, a thermal spring near Joshimath) Water sampling

Water of both the thermal springs was sampled during the year 2014 and 2015 in two sampling operations each year. In both the years, the water sample was collected in the month of June and August to observe any possibility of change among the physico-chemical parameters during the dry and rainy months. The main objective of current study is to explore the microbial diversity in two hot water springs. Water samples were collected from the origin place of both the hot water springs in autoclaved thermoflask. However, water samples collected for the isolation and identification of

culturable microbial diversity was placed in an ice box filled with freezed ice packs and analyzed within 24 hours. Few of the water quality parameters like $\mathrm{pH}$, water temperature, dissolved oxygen and free carbon dioxide were measured at the sampling site whereas, for the remaining physico-chemical characteristics, the water samples were transferred to the Laboratory of Environmental Microbiology and Biotechnology, Department of Environmental Sciences, H.N.B. Garhwal University, Srinagar-Garhwal, Uttarakhand, India at its earliest possible. All the physico-chemical characteristics were analyzed by following the standard protocols available in APHA, (2005) and microbial diversity by following the standard methods outlined in Harley and Prescott, (2002); Morello et al., (2003).

\section{Physico-chemical characteristics}

Water samples were analyzed for a predefined set of physical and chemical characteristics. Water temperature was measured by dipping the digital thermometer $10 \mathrm{~cm}$ in the hot water of the spring carefully and noted down the readings. The temperature range of digital thermometer was $\left(-50{ }^{\circ} \mathrm{C}\right.$ to $\left.+300{ }^{\circ} \mathrm{C}\right)$ $\mathrm{pH}$ was measured both at the site by using portable $\mathrm{pH}$ meter of Electronics India (Model No. 7011) and in the laboratory by using the Toshcon bench top multiparameter analyzer (Model No. TPC-17). Dissolved oxygen was measured by using the modified Winkler method at the sampling site. Conductivity, salinity and total dissolved solids (TDS) were measured by using the Toshcon

Bench Top Multiparameter analyzer (Model No. TPC-17). Free $\mathrm{CO}_{2}$, total alkalinity, chlorides, total hardness, Calcium and Magnesium were measured by following the protocols outlined in APHA, (2005). Nitrates, Sulphates and Phosphates were measured by Spectrophotometric method by using Systronic UV-VIS Spectrophotometer (model No. 117).

\section{Microbal isolation and enumeration}

Nutrient Agar media (HiMEDIA) was used for the estimation of colony forming units (CFUs) of bacteria. Media $\mathrm{pH}$ for microbial isolation was adjusted according to the $\mathrm{pH}$ of sampling sites. SDA media was used for isolation of fungal species. It was supplemented with $50 \mathrm{mg} / \mathrm{l}$ of each (Streptomycin and Ampicillin) to prevent the bacterial contamination. AIA media was used for the isolation of actinomycetes. After the isolation of microbial colonies, each unique colony was streaked on separate media plate to get the pure culture of each microbial colony (Clesceri et al., 1998).

\section{Morphological studies}

To study the morphological characteristics, the purified selected microbia isolates were observed by naked eyes and under the Phase Contrast Microscope (Nikon Eclipse TS100). Morphology of selected bacterial isolates that was observed in the laboratory is given in Table 1.

Table 1 Morphological and Biochemical characterization of bacterial isolates identified from hot springs of the Garhwal Himalaya

\begin{tabular}{|c|c|c|c|c|c|c|}
\hline \multirow{2}{*}{ Characteristics } & \multicolumn{6}{|c|}{ Bacterial Isolates } \\
\hline & $\begin{array}{l}\text { Brevibacillus } \\
\text { parabrevis }\end{array}$ & $\begin{array}{l}\text { Bacillus } \\
\text { cerus }\end{array}$ & $\begin{array}{l}\text { Geobacillus } \\
\text { stearothermophilus }\end{array}$ & $\begin{array}{l}\text { Streptococcus } \\
\text { pyogenes }\end{array}$ & Bacillus cibi & Bacillus subtilis \\
\hline Shape & Round & Round & Circular & Spherical & Circular & Round \\
\hline Size & $2 \mathrm{~mm}$ & $2-5 \mathrm{~mm}$ & $2-3 \mathrm{~mm}$ & $1 \mathrm{~mm}$ & $3-4 \mathrm{~mm}$ & $2-3 \mathrm{~mm}$ \\
\hline Margin & Smooth & Smooth & Entire & Smooth & Irregular & Lobate \\
\hline Elevation & Flat & Undulate & Convex & Convex & Raised & Flat \\
\hline Color & Yellowish grey & Grayish yellow & Cream & Translucent & Orange yellow & White \\
\hline Cell shape & Rod & Rod & Rod & Cocci & Rod & Rod \\
\hline Spore formation & + & + & + & - & + & - \\
\hline Motility & Motile & Motile & Motile & Non-motile & Motile & Motile \\
\hline Grams staining & $\mathrm{v}$ & + & + & + & $\mathrm{V}$ & + \\
\hline Flagella & Peritrichous & Peritrichous & Monotrichous & Atrichous & Peritrichous & Peritrichous \\
\hline Catalase & + & + & - & - & + & + \\
\hline Citrate & $\mathrm{V}$ & + & $\mathrm{v}$ & + & + & + \\
\hline Urease & - & + & - & - & - & - \\
\hline Methyl Red (MR) & - & - & - & - & - & - \\
\hline Voges Proskauer (VP) & - & + & - & - & - & + \\
\hline Fructose & - & + & - & + & + & + \\
\hline Indole Test & - & - & - & - & - & - \\
\hline Raffinose & - & - & - & - & + & + \\
\hline Ribose & + & + & + & - & - & + \\
\hline Sorbitol & - & - & - & - & - & + \\
\hline Sucrose & $\mathrm{v}$ & $\mathrm{V}$ & - & + & + & + \\
\hline Xylose & - & - & + & - & - & + \\
\hline Trehalose & + & + & - & + & + & + \\
\hline Mannose & - & - & - & + & + & + \\
\hline Mannitol & + & - & + & - & - & + \\
\hline Lactose & - & - & - & + & - & $\mathrm{V}$ \\
\hline Maltose & + & + & - & + & + & + \\
\hline
\end{tabular}

Abbreviations: +: positive; -: negative; v: variable

\section{Biochemical tests}

Moreover, detailed biochemical characterizations were carried out to identify the bacterial and archeal isolates from the hot water spring, up to possible genus or species level. The result of biochemical tests for selected bacterial isolates recorded in the laboratory is given in Table 1. Identification of all the funga isolates were made by microscopic analysis by using the taxonomic keys and standard procedures. To confirm the identification of the microbes done in the laboratory, the pure culture of each isolate was collected and then sent for further identification and confirmation to National Centre for Microbial Resources (NCMR), National Centre for Cell Sciences (NCCS), Pune by using the MALDITOF MS.

\section{Statistical analysis}

Statistical treatment (minimum; maximum; mean; standard deviation) of the physico-chemical parameters of water was conducted. 


\section{RESULTS AND DISCUSSION}

\section{Physico-chemical characteristics}

Data of all the fifteen physico-chemical characteristics obtained under two sampling operations each year during a period of two years (2014-2015) from the Ringigad and Saldhar hot water springs of the Garhwal Himalaya. The data for physico-chemical parameters of Ringigad and Saldhar hot water springs has been presented in Table $2 \& 3$.

The minimum water temperature of Ringigad thermal spring was recorded $82^{\circ} \mathrm{C}$ as minimum and $89^{\circ} \mathrm{C}$ as maximum at the site. The $\mathrm{pH}$ of water of Ringigad thermal spring varied from 6.7 to 6.9 , indicated the slightly acidic nature of water. Similar range of $\mathrm{pH}$ was also recorded by Kumar et al. (2013) for hot springs of Kullu district in Himachal Pradesh; Singh et al. (2015) for hot springs of Jharkhand and West Bengal region; Ghilamicael et al. (2017) for hot springs in Eritrea.

The value of dissolved oxygen (DO) varied from $0.8 \mathrm{mg} / \mathrm{l}$ to $1.2 \mathrm{mg} / \mathrm{l}$. Dissolved oxygen concentration is inversely proportional to the temperature. As the temperature of water goes up the concentration of dissolved oxygen in the water goes down (Rana et al. 2018). Fazlzadeh et al. (2017) recorded the DO concentration within a range of $3.25 \mathrm{mg} / 1$ to $3.57 \mathrm{mg} / \mathrm{l}$ for thermal springs in Iran. The electrical conductivity (EC) was ranged from $4.48 \mathrm{mS} / \mathrm{cm}$ to $4.68 \mathrm{mS} / \mathrm{cm}$ in the water of hot spring. Haki and Gezmu (2012) recorded the similar range of electrical conductivity for the hyperthermal springs of Ethiopia. Salinity of the samples ranged from $2.1^{\mathrm{SAL}}$ to $2.3^{\mathrm{SAL}}$ throughout the sampling period. Similar range of salinity was also recorded by Hamzah $\boldsymbol{e t}$ al. (2013) for thermal springs of Malaysia.

The concentration of total dissolved solids (TDS) was ranged between $2.47 \mathrm{mg} / \mathrm{l}$ to $2.53 \mathrm{mg} / \mathrm{l}$ in the water of Ringigad thermal spring. High range of total dissolved solids was recorded by Hamzah et al. (2013) for thermal springs of Malaysia. The concentration of free $\mathrm{CO}_{2}$ was ranged between $35.2 \mathrm{mg} / \mathrm{l}$ and 48.4 $\mathrm{mg} / \mathrm{l}$ during the study period.

The concentration of total hardness varied from $228 \mathrm{mg} / \mathrm{l}$ to $234 \mathrm{mg} / \mathrm{l}$. High range of alkalinity (196 mg/l) was recorded by Kumar et al. (2013) for thermal springs of Kullu district in Himachal Pradesh. The concentration of Calcium varied from $63.2 \mathrm{mg} / \mathrm{l}$ to $69.6 \mathrm{mg} / \mathrm{l}$. Magnesium concentration varied from $14.20 \mathrm{mg} / \mathrm{l}$ to $17.13 \mathrm{mg} / \mathrm{l}$. A similar range $(12.60 \mathrm{mg} / \mathrm{l}$ to $15.62 \mathrm{mg} / \mathrm{l})$ of magnesium was recorded by Singh et al. (2015) for thermal springs of Jharkhand and West Bengal. The concentration of chlorides varied from $11.36 \mathrm{mg} / 1$ to $14.2 \mathrm{mg} / \mathrm{l}$ concentration observed in the sample. Extreme high range of alkalinity (197.38 $\mathrm{mg} / \mathrm{l}$ ) was recorded by Kumar et al. (2013) for thermal springs of Kullu district in Himachal Pradesh.

Alkalinity of the water ranged from $270.0 \mathrm{mg} / 1$ to $300 \mathrm{mg} / \mathrm{l}$ during the study period. However, a very high range $(165.2 \mathrm{mg} / \mathrm{l})$ of alkalinity was recorded by Kumar et al. (2013) for thermal springs of Kullu district in Himachal Pradesh. The concentration of nitrates present in the water sample was ranged from $0.239 \mathrm{mg} / \mathrm{l}$ to $0.256 \mathrm{mg} / \mathrm{l}$. Sulphates concentration were also found within a range of $0.276 \mathrm{mg} / 1$ to $0.289 \mathrm{mg} / \mathrm{l}$. The concentration of phosphates in the water sample was ranged from $0.026 \mathrm{mg} / \mathrm{l}$ to $0.028 \mathrm{mg} / \mathrm{l}$. A very high range of sulphates and nitrates were recorded by Sherpa et al. (2013) for thermal springs of Sikkim in India.

The minimum water temperature of Saldhar thermal spring was recorded $87^{\circ} \mathrm{C}$ as minimum and $92^{\circ} \mathrm{C}$ as maximum at the site. The $\mathrm{pH}$ of water of Saldhar thermal spring varied from 9.1 to 9.3 , indicating that the water is alkaline in nature. This high $\mathrm{pH}$ may be due to the presence of cyanobacteria present at the site in the form of algal mat. The cyanobacteria use the carbonates and bicarbonates that increase the $\mathrm{pH}$ of the water at a high level. Similar range of $\mathrm{pH}(6.9-9.5)$ was recorded by Singh et al. (2015) for the water samples of thermal springs in Jharkhand and West Bengal of India; Guzman et al. (2004) also recorded the similar range of $\mathrm{pH}$ (7.76 to 9.98) for thermal springs in the pacific coast of Guerrero, Mexico.

The values of dissolved oxygen (DO) varied from $0.4 \mathrm{mg} / \mathrm{l}$ to $0.6 \mathrm{mg} / \mathrm{l}$ Fazlzadeh et al. (2017) recorded the DO concentration within a range of 3.25 $\mathrm{mg} / 1$ to $3.57 \mathrm{mg} / \mathrm{l}$ for thermal springs in Iran and Kumar et al. (2013) recorded $2.52 \mathrm{mg} / \mathrm{l}$ of dissolved oxygen for hot springs of Kullu district in Himachal Pradesh. The electrical conductivity (EC) was ranged from $6.04 \mathrm{mS} / \mathrm{cm}$ to 6.08 $\mathrm{mS} / \mathrm{cm}$ in the water of hot spring. Homma and Tsukahara (2008) recorded the similar range of conductivity for the Northernmost area of the Itoigawa Shizuoka Tectonic Line. Salinity of the samples ranged from $3.0^{\mathrm{SAL}}$ to $3.28^{\mathrm{SAL}}$ throughout the sampling period.

The concentration of total dissolved solids (TDS) was ranged between $3.10 \mathrm{mg} / \mathrm{l}$ to $3.34 \mathrm{mg} / \mathrm{l}$ in the water of Saldhar thermal spring. The concentration of free $\mathrm{CO}_{2}$ was recorded between $30.8 \mathrm{mg} / \mathrm{l}$ and $35.2 \mathrm{mg} / \mathrm{l}$ during the study period. High range of total dissolved solids was recorded by Hamzah et al. (2013) for thermal springs of Malaysia. The concentration of free $\mathrm{CO}_{2}$ was ranged between $35.2 \mathrm{mg} / \mathrm{l}$ and $48.4 \mathrm{mg} / \mathrm{l}$ during the study period.

Table 2 Physico-chemical parameters for water of Ringigad thermal spring in the Garhwal Himalaya

\begin{tabular}{|c|c|c|c|c|c|c|c|}
\hline \multirow{2}{*}{ Physico-chemical Parameters } & \multicolumn{2}{|l|}{2014} & \multicolumn{2}{|l|}{2015} & \multirow[b]{2}{*}{ Min. } & \multirow[b]{2}{*}{ Max. } & \multirow[b]{2}{*}{ Mean \pm SD } \\
\hline & June & August & June & August & & & \\
\hline Water Temperature $\left({ }^{0} \mathrm{C}\right)$ & 82.0 & 89.0 & 83.0 & 87.0 & 82.0 & 89.0 & $85.25 \pm 3.30$ \\
\hline Dissolved oxygen $(\mathrm{mg} / \mathrm{l})$ & 1.2 & 0.8 & 1.2 & 0.8 & 0.8 & 1.2 & $1.0 \pm 0.03$ \\
\hline $\mathrm{pH}$ & 6.7 & 6.8 & 6.9 & 6.8 & 6.7 & 6.9 & $6.8 \pm 0.08$ \\
\hline Conductivity $(\mathrm{mS} / \mathrm{cm})$ & 4.48 & 4.62 & 4.54 & 4.68 & 4.48 & 4.68 & $4.58 \pm 0.09$ \\
\hline Free $\mathrm{CO}_{2}(\mathrm{mg} / \mathrm{l})$ & 35.2 & 44.0 & 35.2 & 48.4 & 35.2 & 48.4 & $40.7 \pm 6.6$ \\
\hline Salinity $\left({ }^{\mathrm{SAL}}\right)$ & 2.3 & 2.3 & 2.1 & 2.3 & 2.1 & 2.3 & $2.25 \pm 0.1$ \\
\hline TDS (mg/l) & 2.47 & 2.51 & 2.49 & 2.53 & 2.47 & 2.53 & $2.5 \pm 0.03$ \\
\hline Chlorides (mg/l) & 11.36 & 14.20 & 14.20 & 14.20 & 11.36 & 14.2 & $13.49 \pm 1.42$ \\
\hline Total Alkalinity (mg/l) & 270.0 & 300.0 & 275.0 & 290.0 & 270.0 & 300.0 & $283.75 \pm 13.77$ \\
\hline Nitrates $(\mathrm{mg} / \mathrm{l})$ & 0.239 & 0.250 & 0.247 & 0.256 & 0.239 & 0.256 & $0.248 \pm 0.01$ \\
\hline Sulphates $(\mathrm{mg} / \mathrm{l})$ & 0.276 & 0.283 & 0.281 & 0.289 & 0.276 & 0.289 & $0.282 \pm 0.01$ \\
\hline Phosphates (mg/l) & 0.026 & 0.028 & 0.028 & 0.027 & 0.026 & 0.028 & $0.027 \pm 0.00$ \\
\hline Total Hardness (mg/l) & 228.0 & 232.0 & 228.0 & 234.0 & 228.0 & 234.0 & $230.5 \pm 3.0$ \\
\hline Calcium (mg/l) & 63.2 & 66.6 & 68.0 & 69.6 & 63.2 & 69.6 & $66.85 \pm 2.72$ \\
\hline Magnesium (mg/l) & 17.13 & 16.5 & 14.20 & 14.70 & 14.2 & 17.13 & $15.63 \pm 1.40$ \\
\hline
\end{tabular}

Table 3 Physico-chemical parameters for water of Saldhar thermal spring in the Garhwal Himalaya

\begin{tabular}{|c|c|c|c|c|c|c|c|}
\hline \multirow{2}{*}{ Physico-chemical Parameters } & \multicolumn{2}{|l|}{2014} & \multicolumn{2}{|l|}{2015} & \multirow[b]{2}{*}{ Min } & \multirow[b]{2}{*}{ Max } & \multirow[b]{2}{*}{ Mean \pm SD } \\
\hline & June & August & June & August & & & \\
\hline Water Temperature $\left({ }^{0} \mathrm{C}\right)$ & 89.0 & 92.0 & 87.0 & 90.0 & 87.0 & 92.0 & $89.5 \pm 2.08$ \\
\hline Dissolved oxygen $(\mathrm{mg} / \mathrm{l})$ & 0.6 & 0.4 & 0.6 & 0.4 & 0.4 & 0.6 & $0.5 \pm 0.12$ \\
\hline $\mathrm{pH}$ & 9.1 & 9.3 & 9.1 & 9.1 & 9.1 & 9.3 & $9.15 \pm 0.10$ \\
\hline Conductivity (mS/cm) & 6.08 & 6.08 & 6.05 & 6.04 & 6.04 & 6.08 & $6.06 \pm 0.02$ \\
\hline Free $\mathrm{CO}_{2}(\mathrm{mg} / \mathrm{l})$ & 30.8 & 35.2 & 30.8 & 30.8 & 30.8 & 35.2 & $31.9 \pm 2.20$ \\
\hline Salinity $\left({ }^{\mathrm{SAL}}\right)$ & 3.14 & 3.00 & 3.28 & 3.16 & 3.0 & 3.28 & $3.15 \pm 0.11$ \\
\hline TDS (mg/l) & 3.10 & 3.18 & 3.34 & 3.34 & 3.1 & 3.34 & $3.24 \pm 0.12$ \\
\hline Chlorides (mg/l) & 9.94 & 14.2 & 9.94 & 12.78 & 9.94 & 14.2 & $11.72 \pm 2.13$ \\
\hline Total Alkalinity (mg/l) & 295.0 & 320.0 & 290.0 & 310.0 & 290.0 & 320.0 & $303.75 \pm 13.77$ \\
\hline Nitrates $(\mathrm{mg} / \mathrm{l})$ & 0.089 & 0.091 & 0.091 & 0.096 & 0.089 & 0.096 & $0.092 \pm 0.00$ \\
\hline Sulphates (mg/l) & 0.287 & 0.311 & 0.296 & 0.310 & 0.287 & 0.311 & $0.301 \pm 0.01$ \\
\hline Phosphates (mg/l) & 0.023 & 0.023 & 0.021 & 0.024 & 0.021 & 0.024 & $0.023 \pm 0.00$ \\
\hline Total Hardness (mg/l) & 248.0 & 256.0 & 252.0 & 256.0 & 248.0 & 256.0 & $253.0 \pm 3.83$ \\
\hline Calcium (mg/l) & 52.0 & 56.11 & 54.4 & 55.2 & 52.0 & 56.11 & $54.43 \pm 1.76$ \\
\hline Magnesium (mg/l) & 28.83 & 28.28 & 28.34 & 28.83 & 28.28 & 28.83 & $28.57 \pm 0.30$ \\
\hline
\end{tabular}


The concentration of total hardness varied from $228 \mathrm{mg} / \mathrm{l}$ to $234 \mathrm{mg} / \mathrm{l}$. High range of alkalinity (196 mg/l) was recorded by Kumar et al. (2013) for thermal springs of Kullu district in Himachal Pradesh. The concentration of Calcium varied from $63.2 \mathrm{mg} / \mathrm{l}$ to $69.6 \mathrm{mg} / \mathrm{l}$. Magnesium concentration varied from $14.20 \mathrm{mg} / \mathrm{l}$ to $17.13 \mathrm{mg} / \mathrm{l}$. A similar range $(12.60 \mathrm{mg} / \mathrm{l}$ to $15.62 \mathrm{mg} / \mathrm{l})$ of magnesium was recorded by Singh $\boldsymbol{e t}$ al. (2015) for thermal springs of Jharkhand and West Bengal.

The concentration of total hardness varied from $248 \mathrm{mg} / \mathrm{l}$ to $256 \mathrm{mg} / \mathrm{l}$. The concentration of Calcium varied from $52.20 \mathrm{mg} / \mathrm{l}$ to $56.11 \mathrm{mg} / \mathrm{l}$. Magnesium concentration varied from $28.28 \mathrm{mg} / \mathrm{l}$ to $28.83 \mathrm{mg} / \mathrm{l}$. The concentration of chlorides varied from $9.94 \mathrm{mg} / \mathrm{l}$ to $14.20 \mathrm{mg} / \mathrm{l}$ observed in the water sample. Alkalinity of the water ranged from $290 \mathrm{mg} / \mathrm{l}$ to $320 \mathrm{mg} / \mathrm{l}$ during the study period The concentration of nitrates present in the water sample was ranged from 0.089 $\mathrm{mg} / \mathrm{l}$ to $0.096 \mathrm{mg} / \mathrm{l}$. Sulphates concentration were also found within a range of $0.287 \mathrm{mg} / \mathrm{l}$ to $0.311 \mathrm{mg} / \mathrm{l}$. The concentration of phosphates in the water sample was ranged from $0.021 \mathrm{mg} / \mathrm{l}$ to $0.24 \mathrm{mg} / \mathrm{l}$.

\section{Microbial diversity}

In Ringigad, an overall, seven species of bacteria (Brevibacillus borstelensis, Aeromonas veronii, Paenibacillus dendritiformis, Bacillus cerus, Bacillus cibi, Streptococcus pyogenes and Strenotrophomonas maltophila) and four species of actinomycetes (Streptomyces albus, Streptomyces canescens, Thermoactinomyces candidus and Thermoactinomyces thalopophilum) were recorded. However, three species of fungi (Sclerotium rolfsii, Fusarium oxysporum and Sclerotinia sclerotiorum) were also recorded. The $\alpha$-diversity of microbes in the Ringigad thermal spring was found to be fourteen during the study period (Table 4). In Saldhar, an overall, six species of bacteria (Bacillus cerus, Streptococcus pyogenes, Bacillus subtilis, Brevibacillus parabrevis, Brevibacillus reuszeri and Geobacillus stearothermophilus) and three species of actinomycetes (Streptomyces albus, Thermoactinomyces candidus and Thermoactinomyces thalopophilum) were recorded. However, three species of fungi (Aspergillus tubingensis, Trichoderma harzianum and

Sclerotinia sclerotiorum) were also recorded. The $\alpha$-diversity of microbes in Saldhar spring was found to be twelve during the study period (Table 4). The microbes that were found in both the thermal springs were typical to other thermal springs. All the microbial species are hyperthermophiles and can be identified only in the thermal springs having such an extreme temperature.

Table 4 Microbial diversity of Ringigad and Saldhar hot water springs of Garhwal Himalaya (Abbreviations: +: present; -: absent)

\begin{tabular}{lcc}
\hline Microorganisms & Ringigad & Saldhar \\
\hline Bacteria & & \\
\hline Brevibacillus borestelensis & + & - \\
\hline Aeromonas veronii & + & - \\
\hline Stenotrophomonas maltophilia & + & - \\
\hline Paenibacillus dendritiformis & + & - \\
\hline Bacillus cerus & + & + \\
\hline Bacillus cibi & + & - \\
\hline Streptococcus pyogenes & + & + \\
\hline Bacillus subtilis & - & + \\
\hline Brevibacillus parabrevis & - & + \\
\hline Brevibacillus reuszeri & - & + \\
\hline Geobacillus stearothermophilus & - & + \\
\hline Actinomycetes & & \\
\hline Thermoactinomyces candidus & + & + \\
\hline Thermoactinomyces thalpophilum & + & + \\
\hline Streptomyces albus & + & + \\
\hline Streptomyces canescens & + & - \\
\hline Fungi & & \\
\hline Sclerotium rolfsii & + & - \\
\hline Fusarium oxysporum & + & - \\
\hline Sclerotinia sclerotiorum & + & + \\
\hline Aspergillus tubingensis & - & + \\
\hline Trichoderma harzianum & $\mathbf{1 4}$ & $\mathbf{1 2}$ \\
\hline Total & & \\
\hline & + & + \\
\hline
\end{tabular}

\section{CONCLUSION}

Keeping in view, it has been concluded that both the thermal springs (Ringigad and Saldhar) are having a very high temperature. The concentration of dissolved oxygen is very low in which only the thermophilic microbes can survive. The $\mathrm{pH}$ of both the springs revealed the alkaline nature of the water of the hot springs. Apart of the high temperature, the $\alpha$-diversity of microbes in Ringigad is 14 and in Saldhar it is 12 .

Acknowledgement: One of the authors (Rahul Kumar) is thankfully acknowledge for the fellowship given by the University Grant Commission, New Delhi through Hemvati Nandan Bahuguna Garhwal University (A Central
University), Srinagar-Garhwal, Uttarakhand, India for undertaking the present work.

\section{REFERENCES}

Akmar, H.N., Asma, I., Venugopal, B., Latha, L.Y., Sasidharan, S. (2011) Identification of appropriate sample and culture method for isolation of new thermophilic bacteria from hot spring. African Journal of Microbiology Research, 5(3), 217-221.http://dx.doi.org/10.5897/AJMR10.462

APHA (2005). Standard methods for the estimation of water and wastewater. American Public Health Association, American Waste Water Association and Water Pollution Control Federation. 21 $1^{\text {st }}$ Edition, Washington. https://dx.doi.org/10.2105/ajph.51.6.940-a

Beg, Q.K., Bhushan, B., Kapoor, M., Hoondal, G.S. (2000). Production and characterization of thermostable xylanase and pectinase from Streptomyces $\mathrm{sp}$. QG-11-3. Journal of Industrial Microbiology and Biotechnology, 24, 396-402. http://dx.doi.org/10.1038/sj.jim.7000010

Bhardwaj, K.N., Tiwari, S.C., Bahuguna, Y.M. (2010). Screening of thermophilic cyanobacteria isolated from Tapoban Geothermal field,

Uttarakhand Himalaya for the production of antibacterial compounds. Asian Journal of Experimental Biology and Sciences, 1(4), 787-791.

Bhusare, D.U., Wakte, P.S. (2011). Microbiological and physicochemical attributes of hot water sulphur spring of Unkeshwar. Journal of Experimental Sciences, 2(4), 4-6.

Clesceri, L.S., Greenberg, A.E., Eaton, A.D. (1998). Standard Methods for the Examination of Water and Wastewater, 20th edn Baltimore, MA: American Public Health Association, American Water Works Association, Water Environmental Federation. https://dx.doi.org/10.5860/choice.49-6910

Fazlzadeh, M., Sadeghi, H., Bagheri, P., Poureshg, Y., Rostami, R. (2016) Microbial quality and physical-chemical characteristics of thermal springs. Environmental Geochemistry and Health, 38, 413-422. http://dx.doi.org/10.1007/s10653-015-9727-7

Ghati, A., Sarkar, K., Paul, G. (2013). Isolation, characterization and molecular identification of Esterolytic bacteria from an Indian Hot spring. Current Research in Microbiology and Biotechnology, 1(4), 196-202.

Ghilamicael, A.M., Boga, H.I., Anami, S.E., Mehari, T., Budambula, N.L.M. (2017). Physical and chemical characteristics of five hot springs in Eritrea. Journal of Natural Sciences Research, 7(12), 88-94.

Guzman, A.R., Taran, Y., Armienta, M.A. (2004). Geochemistry and origin of high-pH thermal springs in the Pacific coast of Guerrero, Mexico. Geofisica International, 43(3), 415-425.

Haki, G.D., Gezmu, T.B. (2012). Physico-chemical properties of waters from some Ethiopian hot springs and the risk to the health of the community. Greener Journal of Physical Sciences, 2(4), 138-140.

Hamzah, Z., Rani, N.L.A., Saat, A., Wood, A.K. (2013). Determination of hot springs physico-chemical water quality potentially use for Balneotherapy. Malaysian Journal of Analytical Sciences, 17(3), 436-444.

Harley, J.P., Prescott, L.M. (2002). Laboratory exercises in microbiology. The MacGraw Hill publication. $5^{\text {th }}$ Edition, 1-445.

Homma, A., Tsukahara, H. (2008). Chemical Characteristics of Hot Spring Water and Geological Environment in the Northernmost Area of the Itoigawa Shizuoka Tectonic Line. Bulletin of the Earthquake Research Institute, University of Tokyo, 83, 217-225.

Huang, Q., Dong, C.Z., Dong, R.M., Jiang, H., Wang, S., Wang, G., Fang, B., Ding, X., Niu, L., Li, X., Zhang, C., Dong, H. (2011). Archaeal and bacterial diversity in hot springs on the Tibetan Plateau, China. Extremophiles, 15, 549563. http://dx.doi.org/10.1007/s00792-011-0386-z

Kumar, B., Trivedi, P., Mishra, A.K., Pandey, A., Palni, L.M.S. (2004) Microbial diversity of soil from two hot springs in Uttaranchal Himalaya. Microbiological Research, 159, 141-146. http://dx.doi.org/10.1016/j.micres.2004.01.004

Kumar, N., Singh, A., Sharma, P. (2013). To study the Physico-Chemical properties and Bacteriological examination of Hot Spring water from Vashisht region in Distt. Kullu of HP, India. International Research Journal of Environmental Sciences, 2(8), 28-31.

Morello, J.A., Granato, P.A., Mizer, H.E. (2003). Laboratory manual and workbook in Microbiology. The MacGraw Hill Publication. $7^{\text {th }}$ Edition, 1-285. https://doi.org/10.1016/s0001-2092(07)61019-9

Pathak, A.P., Rathod, M.G. (2014). Cultivable bacterial diversity of terrestrial thermal spring of Unkeshwar, India. Journal of Biochemical Technology, 5(4). 814-818.

Rana, K.S., Sharma, R.C., Tivari, V., Kumar, R. (2018). Assessment of surface water quality of the Himalayan lake Beni Tal, India. Current Research in Hydrology and Water Resources, 1, 1-11. http://dx.doi.org/10.29011/CRHR-102. $\underline{100002}$

Rawat, S. (2015). Bacterial diversity of a sulphur spring in Uttarakhand, India. Advances in Applied Science Research. 6(4), 236-244.

Rothschild, L., Manicineli, R. (2001). Life in extreme environments. Nature, 409, 1092-1101. http://dx.doi.org/10.1038/35059215 
Sen, S.K., Mohapatra, S.K, Satpathy, S., Rao, G.T.V. (2010). Characterization of hot water spring source isolated clones of bacteria and their industrial applicability. International Journal of Chemical Research, 2, 1-7. https://dx.doi.org/10.9735/0975-3699.2.1.1-7

Sharma, A., Pandey, A., Shouche, Y.S., Kumar, B., Kulkarni, G. (2008). Characterization and identification of Geobacillus spp. isolated from Soldhar hot spring site of Garhwal Himalaya, India. Journal of Basic Microbiology, 48, 1-8. http://dx.doi.org/10.1002/jobm.200800194

Sherpa, M.T., Das, S., Thakur, N. (2013). Physicochemical analysis of hot water springs of Sikkim-Polok Tatopani, Borong Tatopani and Reshi Tatopani. Recent Research in Science and Technology, 5(1), 63-67.

Singh, H.K., Chandrasekharam, D., Vaselli, O., Trupti, G., Singh, B., Lashin, A.

Arifi, N.A. (2015). Physico-chemical characteristics of Jharkhand and West Bengal thermal springs along SONATA mega lineament, India. Journal of Earth System Science, 124(2), 419-430. https://dx.doi.org/10.1007/s12040-015-0550-4

Tekere, M., Lötter, A, Olivier, J., Venter, S. (2015). Bacterial diversity in some South African Thermal Springs: A metagenomic analysis. Proceedings World Geothermal Congress, Melbourne, Australia. 1-8. 